\title{
Effect of smartphone addiction on loneliness levels and academic achievement of $\mathrm{z}$ generation
}

\author{
İlimdar Yalçın' ${ }^{1}$ Burhan Özkurt², Murat Özmaden ${ }^{3}$, Rıfat Yağmur ${ }^{4}$
}

${ }^{1}$ Bingöl University, Bingöl, Turkey

${ }^{2}$ Sivas Cumhuriyet University, Sivas

${ }^{3}$ Adnan Menderes University, Aydin

${ }^{4}$ Afyon Kocatepe University, Afyon, Turkey

\section{ARTICLE INFO}

Article History:

Received 01.10.2019

Received in revised form

12.12.2019

Accepted 27.12.2019

Available online

31.01.2020

\begin{abstract}
Smartphones provide users much more than a mobile phone. For this reason, smartphones have become very important in our lives. In this context, the aim of this study was to investigate the effect of smartphone addiction on loneliness levels and academic achievement of $Z$ generation high school students. In 2018-2019 academic year' spring semester, 490 high school students voluntarily participated to this study. As well as demographic information, Smartphone Addiction Scale and UCLA Loneliness Scale were used. In the analyses of the obtained data, IBM SPSS Statistics 24 was used. The relationship between variables was analyzed using Pearson's Correlation analysis. To determine the effect of smartphone addiction on high school students' loneliness and academic achievements, linear regression analysis was used. A positive relationship between $Z$ generation high school students' smartphone addiction and right of monthly GB usage for smartphone, daily internet usage duration, and loneliness levels was determined, whereas there was a negative correlation between their academic achievements. Moreover, it was found that smartphone addiction of $Z$ generation high school students predicted their loneliness and academic achievement at the level of $\sim 4 \%$ and $\sim 1 \%$, respectively. These results show that high school students should be saved from smartphone addiction. Thus, loneliness levels can be reduced and academic achievement can be increased.
\end{abstract}

(c) 2020 IJPES. All rights reserved

Keywords:

Academic achievement; Loneliness; Smartphone addiction; Z generation

\section{Introduction}

Generally, living in the same period and/or individuals with similar characteristics can be defined as generations. In the 21st century generation classification is classified as Traditionalists (1925-1945), the Baby Boomer (1946-1964), Generation X (1965-1979), Generation Y (1980-1999), and Generation Z (2000-2020). Each generation has its own characteristics. Generally, Traditionalists can be seen in the tendency to be frugal and cautious or risk-averse and seeing conformity as a sure ticket to success. Generations born in the years immediately after World War II represent the generation of the Baby Boomers. Generation X is reconciled with technology and knowledge, entrepreneurial, goal-oriented, and independent. Generation $Y$ is the first generation to grow with the appeal of digital media, and two-thirds of its members met computers before the age of five. Lastly, the $Z$ generation is called the internet generation (Adıgüzel, Batur \& Ekşili, 2014).

\footnotetext{
${ }^{1}$ Corresponding author's address: School of Physical Education and Sports, Bingöl University, Bingöl, Turkey

Telephone: +90 (546) 4240023

e-mail: ilimdaryalcin@gmail.com

http://dx.doi.org/10.17220/ijpes.2020.01.017
} 
Since the 1990s, the internet has played a distinctive role in the lives of Generation Z youth. Toronto (2009) have reported that the internet has become a defining characteristic of a global society. Previously, the addictive use of the internet has not been identified formally as a problematic behavior by sociologists, psychologists, or psychiatrists (Young, 1998). However nowadays, as addiction not only refers to a drug or substance abuse, but it also refers to gambling, internet, games, or even smartphones, this kind of addictions fall under the category of behavioral addiction (Kwon, 2013). Therefore, it can be said that some internet users were becoming addicted to the internet in the same way that others became addicted to drugs or alcohol which resulted in academic, social, and occupational impairment.

The rapidly developing technological instruments have changed our daily behaviors and habits on a wide range including communication and information (Şar, Ayas \& Horzum, 2015). First of all, together with the technological developments televisions, computers, cell phones, internet and lastly smartphones have become very important in our lives (Soyer, Tolukan \& Dugenci, 2019). Today smartphones provide users much more than a mobile phone. They offer camera, offline and online games, and thousands of applications available via the Internet (Enez Darcin et al., 2016). However, smartphones can be detrimental to the user's health if they are used in a problematic or addictive manner. Bianchi and Phillips (2005) have indicated that excessive use of mobile phone may cause health problems more (e.g. headaches, fatigue, impaired concentration, insomnia, and hearing problems). It was also reported that some dimensions of personality such as low self-esteem, extraversion, higher approval motivation, and higher self-monitoring were more frequently seen in people who suffer from mobile phone addiction. In addition to these problematic behaviors, smartphone addiction can affect individuals' loneliness and academic achievement.

Loneliness is a serious and major developmental problem of adolescence. Individuals seek various ways to cope with this problem. Problematic mobile phone use, even among family members, negatively affects faceto-face interpersonal contact resulting in anti-social feelings (Dayapoglu, Kavurmaci \& Karaman, 2016). Şar (2013) reported that the percentage of daily mobile phone usage duration was higher in adolescents feeling lonely and addicted to mobile phones. Moreover, smartphone addiction was found to be associated with the behavioral problems of low social skills (Engelberg \& Sjöberg, 2004), low self-confidence, and low self-esteem. On the other hands, the health risks associated with mobile phones include increased chances of anxiety or depression, bullying, eye strain, headache, and hearing loss (Parasuraman, 2017).

Academic achievement at school is an important component of school-related experiences (Kim, Ahn \& Lee, 2019). Especially, generation $Z$ was born in a technologically rich period. Therefore, it is known that smartphones are popular and widely used among the $Z$ generation youth. However, many studies have stated that smartphone addiction and excessive and/or problematic smartphone use is negatively associated with academic achievement (Junco \& Cotten, 2012; Lin et al., 2014; Lepp, Barkley \& Karpinski, 2014). Tindell and Bohlander (2012) indicated that the majority of students use smartphones in the classroom. Moreover, Lin et al. (2014) have emphasized that the sleep quality of young smartphone addicts with low academic success decreased due to the smartphone use in bed and it was stated that they were interested in a smartphone while studying.

Smartphones can provide us access information faster. However, the excessive use or addiction of smartphones can lead to academic failure or loneliness. Therefore, it is important to determine the effect of smartphone addiction, especially on the level of loneliness and academic achievement of the $\mathrm{z}$ generation. The research questions of this study are as follows;

$\mathrm{H}_{1}$ : Smartphone addiction has a positive effect on loneliness.

$\mathrm{H}_{2}$ : Smartphone addiction has a negative effect on academic achievement.

In this context, the aim of the present study was to determine the effect of smartphone addiction on loneliness levels and academic achievement of $\mathrm{z}$ generation high school students. 


\section{Method}

\subsection{Model of the research and Participants}

The relational screening model (from the general screening model) was used as the research model. Convenience sampling method was used for the sampling selection and face to face survey method was preferred in the data collection. At the beginning of the study, the purpose and importance of the study was explained to the high school students by the researchers and their voluntary participation was provided. The study procedures were carried out in accordance with the Declaration of Helsinki. In 2018-2019 academic year' spring semester, 490 high school students participated to this study. The survey consists of four sections, namely personal information form, academic achievement, loneliness, and smartphone addiction scales, respectively. All participants' demographic characteristics in the personal information was determined using survey questions. Furthermore, all of the students participate to the study own and use a mobile phone regularly. Moreover, all students were users of at least one social media (e.g. Facebook, Instagram, and Twitter). Body mass indexes of the students were categorized by using Z score tables of WHO-BMI for age standards for children and adolescents between 5 and 19 years for boys and girl, separately (WHO, 2007). Demographic characteristics of the $\mathrm{Z}$ generation high school students were given below.

Table 1. Demographic characteristics of the $\mathrm{Z}$ generation high school students

\begin{tabular}{|c|c|c|c|c|c|c|c|c|c|}
\hline \multicolumn{2}{|r|}{ Variables } & & $\mathbf{F}$ & $\%$ & \multicolumn{3}{|c|}{ Variables } & $\mathbf{F}$ & $\%$ \\
\hline \multirow{5}{*}{\multicolumn{2}{|c|}{$\underset{4}{4}$}} & 14 & 19 & 3.9 & \multirow{4}{*}{ 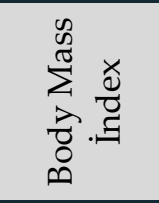 } & \multicolumn{2}{|c|}{ Thinness } & 11 & 2.2 \\
\hline & & 15 & 53 & 10.8 & & \multicolumn{2}{|c|}{ Normal } & 397 & 81.0 \\
\hline & & 16 & 155 & 31.6 & & \multicolumn{2}{|c|}{ Overweight } & 73 & 14.9 \\
\hline & & 17 & 151 & 30.8 & & \multicolumn{2}{|c|}{ Obesity } & 9 & 1.8 \\
\hline & & 18 & 112 & 22.9 & \multirow{8}{*}{ 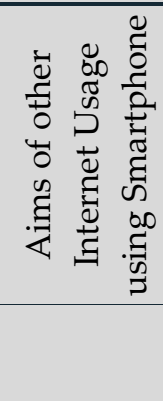 } & \multirow{2}{*}{ Homework } & Yes & 244 & 49.8 \\
\hline \multirow{3}{*}{\multicolumn{2}{|c|}{$\begin{array}{l}\bar{v} \\
\overline{0} \\
\tilde{D} \\
0\end{array}$}} & Girls & 221 & 45.1 & & & No & 246 & 50.2 \\
\hline & & \multirow{2}{*}{ Boys } & \multirow{2}{*}{269} & \multirow{2}{*}{54.9} & & \multirow{2}{*}{ Games } & Yes & 329 & 67.1 \\
\hline & & & & & & & No & 161 & 32.9 \\
\hline \multirow{6}{*}{ 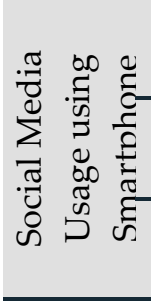 } & \multirow{2}{*}{ Facebook } & Yes & 254 & 51.8 & & \multirow{4}{*}{\multicolumn{2}{|c|}{ Movies }} & 315 & 64.3 \\
\hline & & No & 236 & 48.2 & & & & 175 & 35.7 \\
\hline & \multirow{2}{*}{ Instagram } & Yes & 408 & 83.3 & & & & \multirow{2}{*}{\multicolumn{2}{|c|}{$\bar{X} \pm \mathrm{SD}$}} \\
\hline & & No & 82 & 16.7 & & & & & \\
\hline & \multirow{2}{*}{ Twitter } & Yes & 220 & 44.9 & \multirow{2}{*}{\multicolumn{3}{|c|}{$\begin{array}{l}\text { Right of monthly GB usage for } \\
\text { Smartphone }\end{array}$}} & \multirow{2}{*}{\multicolumn{2}{|c|}{$5.92 \pm 4.09$}} \\
\hline & & No & 270 & 55.1 & & & & & \\
\hline \multirow{4}{*}{ 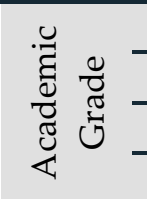 } & \multicolumn{2}{|c|}{$1^{\text {st }}$ class } & 140 & 28.6 & \multirow{2}{*}{\multicolumn{3}{|c|}{$\begin{array}{c}\text { Daily internet usage } \\
\text { duration (min.) using Smartphone }\end{array}$}} & \multirow{2}{*}{\multicolumn{2}{|c|}{$194.16 \pm 134.49$}} \\
\hline & \multicolumn{2}{|c|}{$2^{\text {nd }}$ class } & 166 & 33.9 & & & & & \\
\hline & \multicolumn{2}{|c|}{$3^{\text {rd }}$ class } & 125 & 25.5 & \multirow{2}{*}{\multicolumn{3}{|c|}{$\begin{array}{c}\text { Grade Point Average } \\
\text { (Academic Achievement) }\end{array}$}} & \multirow{2}{*}{\multicolumn{2}{|c|}{$76.77 \pm 10.77$}} \\
\hline & \multicolumn{2}{|c|}{$4^{\text {th }}$ class } & 59 & 12.0 & & & & & \\
\hline
\end{tabular}

\subsection{Data Collection Tools}

Smartphone addiction scale. In order to determine the risk of smartphone addiction of the participants, Smartphone Addiction Scale developed by Kwon et al. (2013) and adapted to the Turkish language by Noyan et al. (2015) was used. Turkish version of the smartphone addiction scale consisted of one-dimension and 10 items. Scale rating was in order from 1 to 6 (Absolutely Disagree and Absolutely Agree). The total score of the scale ranged from 10 to 60 . As the scores obtained from the scale increase, the risk for addiction increases. The Cronbach alpha value of the scale developed in university students was found to be 0.867 . In this study, the Cronbach alpha value for high school students was found to be 0.905 . This result shows that smartphone addiction scale was reliable for high school students.

UCLA loneliness scale. In order to determine subjective feelings of loneliness or social isolation, UCLA Loneliness Scale short form (ULS-8) developed by Hays and DiMatteo (1987) and adapted to the Turkish language by Yildiz and Duy (2014) was used. The original scale consists of 8 items. However, the factor load of one item ("I am an extrovert person") in the Turkish language is less than 0.30. Therefore, the Turkish 
version of the scale consists of 7 items and one dimension. ULS-8 is a Likert-type scale with 4 options "(1) Never, (2) Rarely, (3) Sometimes and (4) Always". Additionally, "I can find a friend when I want" item is reverse scored. The total score of the scale ranged from 7 to 28 . As the scores obtained from the scale increase, the feelings of loneliness in adolescents increases. The Cronbach alpha value of the scale developed in Turkish adolescents was found to be 0.74 . In this study, the Cronbach alpha value was found to be 0.754 . This result shows that the UCLA Loneliness Scale was reliable for high school students.

\subsection{Statistical analysis}

For data analysis, IBM SPSS Statistics 24 was used. Percentage (\%) and frequency (f) values regarding demographic characteristics of the students were calculated as descriptive statistics. Skewness and Kurtosis values were checked to determine whether the data showed normal distribution. These values were checked and evaluated between +2 and -2 (George \& Mallery, 2003). According to this evaluation, the data showed normal distribution. The relationship between data showing normal distribution was analyzed using Pearson's correlation analysis. To determine the effect of smartphone addiction on high school students' loneliness and academic achievement, linear regression analysis was used. Significance was set at $\mathrm{p}<0.05$.

\section{Results}

Table 2. Results of Pearson's Correlation analysis between variables

\begin{tabular}{lllllll}
\hline Variables & & $\mathbf{1}$ & $\mathbf{2}$ & $\mathbf{3}$ & $\mathbf{4}$ & $\mathbf{5}$ \\
Right of monthly GB usage for Smartphone & $\mathrm{r}$ & 1 & & & & \\
(1) & $\mathrm{p}$ & & & & & \\
Daily internet usage duration & $\mathrm{r}$ & .129 & 1 & & \\
(2) & $\mathrm{p}$ & $.004^{* *}$ & & & \\
Academic achievement & $\mathrm{r}$ & -.131 & -.103 & 1 & & \\
$\mathbf{( 3 )}$ & $\mathrm{p}$ & $.004^{* *}$ & $.022^{*}$ & & & \\
Smartphone addiction & $\mathrm{r}$ & .121 & .102 & -.092 & 1 & \\
$\mathbf{( 4 )}$ & $\mathrm{p}$ & $.007^{* *}$ & $.023^{*}$ & $.043^{*}$ & & \\
Loneliness & $\mathrm{r}$ & .003 & .087 & .033 & .208 & 1 \\
$\mathbf{( 5 )}$ & $\mathrm{p}$ & .942 & .054 & .472 & $.001^{* *}$ & \\
\hline
\end{tabular}

When Table 2 was examined, it was determined that a positive relationship between $\mathrm{Z}$ generation high school students' smartphone addiction and right of monthly GB usage for smartphone, daily internet usage duration, and loneliness levels, whereas a negative correlation between their academic achievements.

Table 3. Results of Linear Regression analysis regarding the effect of smartphone addiction on loneliness and academic achievement

\begin{tabular}{|c|c|c|c|c|c|c|c|c|}
\hline Model & Variables & $\begin{array}{l}\text { Standardized } \\
\text { Coefficients } \beta\end{array}$ & $\mathbf{t}$ & $\mathbf{p}$ & $\mathbf{R}^{2}$ & $\begin{array}{l}\text { Adjusted } \\
\mathbf{R}^{2}\end{array}$ & $\mathbf{F}$ & p \\
\hline \multirow[b]{2}{*}{1} & (Constant) & & 22.444 & $.001^{* *}$ & \multirow[b]{2}{*}{.043} & \multirow[b]{2}{*}{.041} & \multirow[b]{2}{*}{22.161} & \multirow[b]{2}{*}{$.001^{* *}$} \\
\hline & $\begin{array}{l}\text { Smartphone } \\
\text { addiction }\end{array}$ & .208 & 4.708 & $.001^{* *}$ & & & & \\
\hline \multicolumn{5}{|c|}{ Dependent Variable: Loneliness Level } & & & \multicolumn{2}{|c|}{ Method: Enter } \\
\hline \multirow[b]{2}{*}{1} & (Constant) & & 60.375 & $.001^{* *}$ & \multirow[b]{2}{*}{.008} & \multirow[b]{2}{*}{.006} & \multirow[b]{2}{*}{4.129} & \multirow[b]{2}{*}{$.043^{*}$} \\
\hline & $\begin{array}{l}\text { Smartphone } \\
\text { addiction }\end{array}$ & -.092 & -2.032 & $.043^{*}$ & & & & \\
\hline \multicolumn{5}{|c|}{ Dependent Variable: Academic Achievement } & & & \multicolumn{2}{|c|}{ Method: Enter } \\
\hline
\end{tabular}

When Table 3 was examined, it was found that smartphone addiction of $Z$ generation high school students predicted their loneliness and academic achievement at the level of $\sim 4 \%$ and $\sim 1 \%$, respectively. 


\section{Discussion and Conclusion}

According to the primary findings of the study, $490 \mathrm{Z}$ generation high school students (age: 16.58 \pm 1.07 ; Body Mass Index: 21.36 \pm 2.96 ) participated in the study. High school students' $45.1 \%$ were girls and $54.9 \%$ were boys. There was a social media membership of all students (Facebook: 51.8\%; Instagram: 83.3\%; Twitter: 44.9\%) and it was determined that except social media they use their smartphones for doing their homework (49.8\%), playing games $(67.1 \%)$, and watching movies $(64.3 \%)$. As the factors affecting smartphone addiction, the monthly GB usage rights of the smartphones of the students was 5.92 \pm 4.09 GB and the daily internet usage duration was $194.16 \pm 134.49 \mathrm{~min}$. However, It was determined that the grade point average of high school students was $76.77 \pm 10.77$ (Table 1 ).

Smartphone addiction of smartphone users has been changing according to daily routines, habits, social behaviors, emancipative values, family relations, and social interactions. Haug et al (2015) stated that smartphone addiction was more prevalent in younger adolescents (15-16 years) students compared with young adults (19 years and older). When the literature was examined, Montag et al. (2015) indicated daily internet usage duration of smartphone users as $161.95 \pm 83.36 \mathrm{~min}$ while Meithz (2011) stated the daily internet usage duration of students as $196.25 \pm 65.44 \mathrm{~min}$. Daily internet usage durations of high school students who participated in our study are similar to the results in the literature. However, the high monthly GB usage rights in high school students' smartphone can extend their daily internet usage duration. Thus, smartphone usage duration of high school students may increase. As a matter of fact, it was determined that there was a small and positive relationship between monthly GB usage rights of high school students and daily internet usage durations ( $\mathrm{r}=.129 ; \mathrm{p}=.004)$. Moreover, it was found that there was a small and positive relationship between the monthly GB usage rights of the smartphones $(\mathrm{r}=.121 ; \mathrm{p}=.007)$, the daily internet usage duration $(\mathrm{r}=.102$; $\mathrm{p}=.023$ ) and smartphone addiction of the students (Table 2).

In a meta-analysis, Sung, Chang, and Liu (2016) have reported that a moderate and positive effect using mobile phones as an education material and/or a teaching tool. However, Giunchiglia et al. (2018) stated that there was a negative relationship between the usage of social media apps during academic activities (in terms of sessions and duration) and students' academic performances. On the other hand, many studies indicated a negative relationship between smartphones and academic achievement (Lepp, Barkley, \& Karpinski, 2015; Rashid \& Asghar, 2016; Samaha \& Hawi, 2016). Moreover, in another meta-analysis, Kates, Wu, and Coryn (2018) indicated that 36 of studies found a negative relationship and 3 studies reported a positive relationship between smartphone addiction and academic achievement. Furthermore, as a result of this meta-analysis, it was determined that smartphone addiction has a small and negative effect on academic achievement. Considering the results of researches between smartphone addiction and academic achievement, there is no clear consensus regarding the size and direction of the effects of smartphone use on academic performance exists within the scholarly literature. According to the results of the present study, there was a small and negative correlation between daily internet usage duration and academic achievement $(r=-.103 ; p=.022)$. Moreover, there was a small and negative relationship between smartphone addiction and academic achievements ( $r=-.092 ; \mathrm{p}=.043$ ) of the students (Table 2$)$.

It is not clear whether smartphone addiction affects loneliness or loneliness affects smartphone addiction. However, many studies determined a relationship between smartphone addiction and loneliness (Kim, Cho, \& Kim, 2017; Kutlu et al., 2016; Tan, Pamuk, \& Dönder, 2013; Ujang et al., 2016). For instance, Çakır and Oğuz (2017) indicated that there was a moderate level positive relationship between smartphone addiction and loneliness levels of high school students. Dikeç ve ark. (2017) determined that there was a low and positive relationship ( $\mathrm{r}=.202, \mathrm{p}=0.01)$ between smartphone addiction and loneliness levels of high school students. Despite that, Aktürk et al. (2018) expressed that there was no relationship between high school and university students' smartphone addiction and loneliness levels. Moreover, there was no statistically significant relationship between high school and university students' smartphone addiction and loneliness levels.

In the result of the current study, there was a small and positive relationship between smartphone addiction and loneliness levels $(r=.208 ; \mathrm{p}=.001)$ of the students (Table 2). According to the main findings of the study, it was found that smartphone addiction of $\mathrm{Z}$ generation high school students predicted their loneliness (Adjusted R2 $=.041 ; \mathrm{p}=.001$ ) and academic achievement (Adjusted $\mathrm{R} 2=.006 ; \mathrm{p}=.043$ ) at the level of $\sim 4 \%$ and $\sim 1 \%$, respectively (Table 3). Although these results show that there is an effect of smartphone addiction on 
loneliness and academic achievement, we think that this effect is related to the intended use of smartphones. Using smartphones as a teaching tool by high school students provides students to access information faster. Thus, students can access information more practical. Moreover, saving high school students from smartphone addiction (4\% effect on loneliness) may reduce their behavioral addiction like social isolation, social skills, and social withdrawal levels, and even increase their level of face-to-face communication. In addition, the limitation of monthly GB usage rights by their parents may also reduce their daily smartphone usage duration. The apps used by high school students on their smartphones should be supervised and the educational role of these apps should be considered by their parents. In addition, in order to reduce the loneliness levels of high school students, they can be directed to extracurricular or sportive activities.

\section{References}

Adıgüzel, O., Batur, H. Z., \& Ekşili, N. (2014). Generation's changing side and the newly arisen work style after Y-generation: mobile collars. Journal of Süleyman Demirel University Institute of Social Sciences, 19(1), 165-182.

Aktürk, Ü., Budak, F., Gültekin, A., \& Özdemir, A. (2018). Comparison of smartphone addiction and loneliness in high school and university students. Perspectives in psychiatric care, 54(4), 564-570. doi: 10.1111/ppc.12277

Bianchi, A., \& Phillips, J. G. (2005). Psychological predictors of problem mobile phone use. CyberPsychology $\mathcal{E}$ Behavior, 8(1), 39-51. doi: 10.1089/cpb.2005.8.39

Çakır, Ö., \& Oğuz, E. (2017). Lise öğrencilerinin yalnızlık düzeyleri ile akıllı telefon bağımlılığı arasındaki ilişki. Mersin Üniversitesi Eğitim Fakültesi Dergisi, 13(1), 418-429. doi:10.17860/mersinefd.290711

Dayapoglu, N., Kavurmaci, M., \& Karaman, S. (2016). The relationship between the problematic mobile phone use and life satisfaction, loneliness, and academic performance in nursing students. International Journal of Caring Sciences, 9(2), 647-652.

Dikeç, G., Yalnız, T., Bektaş, B., Turhan, A., \& Çevik, S. Relationship between Smartphone Addiction and Loneliness among Adolescents. Bağımlılık Dergisi, 18(4), 103-111.

Enez Darcin, A., Kose, S., Noyan, C. O., Nurmedov, S., Y1lmaz, O., \& Dilbaz, N. (2016). Smartphone addiction and its relationship with social anxiety and loneliness. Behaviour \& Information Technology, 35(7), 520525. doi: 10.1080/0144929X.2016.1158319

Engelberg, E., \& Sjöberg, L. (2004). Internet use, social skills, and adjustment. Cyberpsychology \& Behavior, 7(1), 41-47. doi: 10.1089/109493104322820101

George, D. and Mallery, P. (2003). SPSS for Windows step by step: a simple guide and reference. (4th edition). Boston: Allyn \& Bacon.

Giunchiglia, F., Zeni, M., Gobbi, E., Bignotti, E., \& Bison, I. (2018). Mobile social media usage and academic performance. Computers in Human Behavior, 82, 177-185. doi: 10.1016/j.chb.2017.12.041

Haug, S., Castro, R. P., Kwon, M., Filler, A., Kowatsch, T., \& Schaub, M. P. (2015). Smartphone use and smartphone addiction among young people in Switzerland. Journal of behavioral addictions, 4(4), 299307. doi:10.1556/2006.4.2015.037

Hays, R. D., \& DiMatteo, M. R. (1987). A short-form measure of loneliness. Journal of personality assessment, 51(1), 69-81. doi: 10.1207/s15327752jpa5101_6

Junco, R., \& Cotten, S. R. (2012). No A 4 U: The relationship between multitasking and academic performance. Computers \& Education, 59(2), 505-514. doi: 10.1016/j.compedu.2011.12.023

Kates, A. W., Wu, H., \& Coryn, C. L. (2018). The effects of mobile phone use on academic performance: A metaanalysis. Computers \& Education, 127, 107-112. doi: 10.1016/j.compedu.2018.08.012

Kim, E., Cho, I., \& Kim, E. J. (2017). Structural equation model of smartphone addiction based on adult attachment theory: mediating effects of loneliness and depression. Asian Nursing Research, 11(2), 9297. doi: 10.1016/j.anr.2017.05.002

Kim, S., Ahn, J., \& Lee, B. J. (2019). Why Do Children Become Unhappier as They Get Older? Comparing Key Dimensions of Children's Subjective Well-Being Between 8-and 12-Year-Old Groups in South Korea. Child Indicators Research, 12(1), 9-27. doi:10.1007/s12187-017-9513-4

Kutlu, M., Savcı, M., Demir, Y., \& Aysan, F. (2016). Gençlerin internet bağımlılığı testi kısa formunun Türkçe uyarlaması: Üniversite öğrencileri ve ergenlerde geçerlilik ve güvenilirlik çalışması [Turkish adaptation of Young's Internet Addiction Test-Short Form: a reliability and validity study on university students and adolescents]. Anadolu Psikiyatri Dergisi, 17(1), 69-76. doi: 10.5455/apd.190501 
Kwon, M., Kim, D. J., Cho, H., \& Yang, S. (2013). The smartphone addiction scale: development and validation of a short version for adolescents. PloS one, 8(12), e83558. doi: 10.1371/journal.pone.0083558

Lepp, A., Barkley, J. E., \& Karpinski, A. C. (2014). The relationship between cell phone use, academic performance, anxiety, and satisfaction with life in college students. Computers in Human Behavior, 31, 343-350. doi: 10.1016/j.chb.2013.10.049

Lepp, A., Barkley, J. E., \& Karpinski, A. C. (2015). The relationship between cell phone use and academic performance in a sample of U.S. college students. SAGE Open, 5(1), 1-9. doi: 10.1177/2158244015573169

Lin, Y. H., Chang, L. R., Lee, Y. H., Tseng, H. W., Kuo, T. B., \& Chen, S. H. (2014). Development and validation of the Smartphone Addiction Inventory (SPAI). PloS one, 9(6), e98312. doi: 10.1371/journal.pone.0098312

Meitz, T. G. (2011). Mediality: Aspects of contextual media reception. Empedocles: European Journal for the Philosophy of Communication, 3(2), 197-214. doi: 10.1386/ejpc.3.2.197_1

Montag, C., Błaszkiewicz, K., Sariyska, R., Lachmann, B., Andone, I., Trendafilov, B., ... \& Markowetz, A. (2015). Smartphone usage in the 21st century: who is active on WhatsApp? BMC research notes, $8(1)$, 331-336. doi: 10.1186/s13104-015-1280-z

Noyan, C. O., Darçın, A. E., Nurmedov, S., Yılmaz, O., \& Dilbaz, N. (2015). Validity and reliability of the Turkish version of the Smartphone Addiction Scale-Short Version among university students. Anatolian Journal of Psychiatry, 16, 73-81. doi: 10.5455/apd.176101

Parasuraman, S., Sam, A. T., Yee, S. W. K., Chuon, B. L. C., \& Ren, L. Y. (2017). Smartphone usage and increased risk of mobile phone addiction: A concurrent study. International journal of pharmaceutical investigation, 7(3), 125-131. doi: 10.4103/jphi.JPHI_56_17

Rashid, T., \& Asghar, H. M. (2016). Technology use, self-directed learning, student engagement and academic performance: Examining the interrelations. Computers in Human Behavior, 63, 604-612. doi: 10.1016/j.chb.2016.05.084

Samaha, M., \& Hawi, N. S. (2016). Relationships among smartphone addiction, stress, academic performance, and satisfaction with life. Computers in Human Behavior, 57, 321-325. doi: 0.1016/j.chb.2015.12.045

Şar, A. H. (2013). Examination of loneliness and mobil phone addiction problem observed in teenagers from the some variables. The Journal of Academic Social Science Studies, 6(2), 1207-1220. doi: 10.9761/jasss_709

Şar, A. H., Ayas, T., \& Horzum, M. B. (2015). Developing the smart phone addiction scale and its validity and reliability study. Online Journal of Technology Addiction \& Cyberbullying, 2(1), 1-17.

Soyer, F., Tolukan, E., \& Dugenci, A. (2019). Investigation of the Relationship between Leisure Satisfaction and Smartphone Addiction of University Students. Asian Journal of Education and Training, 5(1), 229-235. doi: 10.20448/journal.522.2019.51.229.235

Sung, Y.-T., Chang, K.-E., \& Liu, T.-C. (2016). The effects of integrating mobile devices with teaching and learning on students' learning performance: A meta-analysis and research synthesis. Computers $\mathcal{E}$ Education, 94, 252-275. doi: 10.1016/j.compedu.2015.11.008

Tan, Ç., Pamuk, M., \& Dönder, A. (2013). Loneliness and mobile phone. Procedia-Social and Behavioral Sciences, 103, 606-611. doi: 10.1016/j.sbspro.2013.10.378

Tindell, D. R., \& Bohlander, R. W. (2012). The use and abuse of cell phones and text messaging in the classroom: A survey of college students. College Teaching, 60(1), 1-9. doi: 10.1080/87567555.2011.604802

Toronto, E. (2009). Time out of mind: Dissociation in the virtual world. Psychoanalytic Psychology, 26(2), 117133. doi: $10.1037 / \mathrm{a} 0015485$

Ujang, S., Yusof, N. M., Rawi, I. N. A. M. M., Azhar, B. N. Y. B., Mohamad, N. A. S., \& Yusoff, Y. N. M. (2016) Smartphone Addiction: Relationship between Gender, Emotional Instability and Loneliness among UiTM Raub Students. KONAKA, 333-338.

World Health Organization. (2007). WHO reference 2007: growth reference data for 5-19 years. World Health Organization. Retrieved from: https://www.who.int/growthref/who2007_bmi_for_age/en/

Yildiz, M. A., \& Duy, B. (2014). Adaptation of the short-form of the UCLA loneliness scale (ULS-8) to Turkish for the adolescents. Dusunen Adam, 27(3), 194-203. doi: 10.5350/DAJPN2014270302

Young, K. S. (1998). Internet addiction: The emergence of a new clinical disorder. Cyberpsychology \& Behavior, 1(3), 237-244. doi: 10.1089/cpb.1998.1.237 